\title{
A FEW CRITICAL REMARKS ON ART. 25/3/F OF THE ROME STATUTE
}

\author{
Igor Vuletic ${ }^{*}$
}

\begin{abstract}
In this paper, the author discusses some possible future perspectives of Art. 25/3/f of the Rome Statute. This article regulates two core institutes of traditional substantial criminal law-an attempt and a voluntary abandonment of an attempt. This is considered to be a huge step in codification of general part of international criminal law since statutes of ad hoc tribunal did not have any such or similar provisions. Other authors in criminal law literature have already argued a lot about the interpretation of specific elements of this provision. Bearing that in mind, in this research, the author discusses the purpose or ratio legis of an attempt and abandonment of an attempt in the Rome Statute. At the same time, the focus is on the quest for changes and modifications of this provision de lege ferenda.
\end{abstract}

INTRODUCTION

I. REMARKS ON THE ATTEMPT: MOVING TOWARDS A MORE COMBINED

LEGISLATIVE APPROACH?

II. REMARKS ON THE ABANDONMENT OF CRIMINAL ATTEMPT: BROADENING

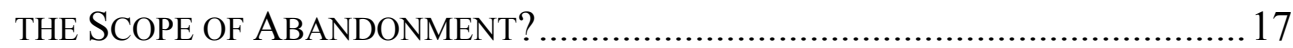

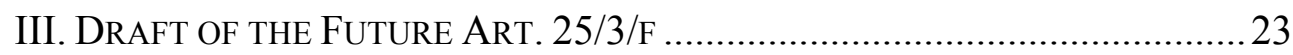

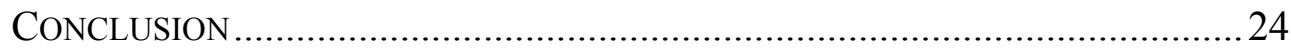

\section{INTRODUCTION}

The Article 25/3/f of the Rome Statute regulates two of the coreinstitutes of substantive criminal law: attempt and voluntary abandonment of an attempt. The Statutes of ad hoc tribunals for former Yugoslavia and Ruanda do not contain any such or similar provisions. Only indirectly, some of the provisions regulating the crime of genocide contain several modalities of conduct and some of these modalities could be considered as criminal attempt or even as preparatory acts. ${ }^{1}$

The Rome Statute, however, for the first time in the history of international criminal law regulates these institutes in a separate provision, similar to the majority of the criminal codes in the countries of Continental Europe.

\footnotetext{
* Igor Vuletić, Ph.D., Assistant Professor of Criminal Law at the Faculty of Law Osijek, Croatia. Research fields: Substantive Criminal Law, International Criminal Law.

${ }^{1}$ See Art. 4 p. 3 (d) of the ICTY Statute and Art. 2 (d) of the ICTR Statute.
} 
The structure of Art. 25/3/f has already been a subject of many scholarly debates. Several authors have given their comments on the essential elements of an attempt. ${ }^{2}$ The focus of these discussions was mainly on the distinction between preparatory acts and an attempt, and the beginning of an attempt. Voluntary abandonment of an attempt, on the other hand, has been considerably neglected by the authors. Bearing this in mind, in this paper, we will try to contribute to these discussions by introducing a novelty, not only about an attempt but also about voluntary abandonment of an attempt.

The structure of the paper is the following: The first paragraph includes our remarks on legislative concept of criminal attempt in the Rome Statute. In the second paragraph, we deal with the problem of voluntary abandonment from criminal attempt in the Rome Statute. Finally, we will give our own suggestion of a possible model of future change of Art. 25/3/f. Our paper addresses primarily the creators of the Rome Statute. Nevertheless, we believe that, some of the given remarks could be useful to the judges of the International Criminal Court (hereinafter: ICC) as interpretative guidelines of Art. 25/3/f of the Rome Statute.

\section{REMARKS ON THE ATTEMPT: MOVING TOWARDS A MORE COMBINED LEGISLATIVE APPROACH?}

As already pointed out in the introduction, international criminal law in the period before the Rome Statute, did not regulate criminal attempt in a separate provision. However, in literature, there was a consensus that the law of attempts was a part of customary international criminal law and that, as such, it represented one of general principles of international criminal law. ${ }^{3}$ Although the ICTY prosecutors showed certain unwillingness to prosecute attempts to commit international crimes, there were many criminal procedures after the World War II which proved that, attempt is the part of international customary law. ${ }^{4}$ In that sense, Art. 25/3/f did not bring any revolutionary change into international criminal law. Instead, it only codified what was already recognized before in practice of ad hoc tribunals.

\footnotetext{
${ }^{2}$ For detailed analysis of Art. 25/3/f see f. e. KAI Ambos, Der AllgemeIne TeIL DES VÖLKERSTRAFRECHTS, (Berlin: Duncker \& Humblot 2002), § 20.

${ }^{3}$ See Gerhard Werle, Principles of International Criminal Law 626 (2th ed., T.M.C. Asser Press 2009).

${ }^{4}$ For details see Robert Cryer, HÁkAn Friman, DARryl Robinson, \& ElizABETH WiLMSHURST, AN InTRODUCTION TO INTERNATIONAL CRIMINAL LAW AND PROCEDURE 383 (Cambridge: Cambridge University Press 2010); see also Helmut SATZGER, InTERNATIONAL AND EUROPEAN CRIMINAL LAW 244-245 (Baden-Baden: C. H. Beck-Hart-Nomos, 2012).
} 
Prior to the regulation of a certain institute of criminal law, every legislator must define the purpose or ratio legis of such institute. This is very important because only a clear definition of ratio legis can set guidelines for interpretation of the concrete provision. This means that, the definition of ratio legis has not only theoretical, but also practical significance. The question of ratio legis is basically a question of why something needs to be regulated.

Now, we will put this question within the context of Art. 25/3/f of the Rome Statute. In the official explanation given by the International Law Commission (hereinafter: ILC), the attempt in the Statute is punishable due to two main reasons. First, it is considered that, there is "a high degree of culpability" attached to a perpetrator who attempted to commit a crime (the so-called subjective approach). Second, "the fact that an individual has taken a significant step towards the completion ... entails a threat to international peace and security because of the very serious nature of these crimes" (the so-called objective approach). This suggests that, ILC was guided by subjective-objective approach, bearing in mind the specific nature and seriousness of these crimes and the need for prevention at the earliest possible stage. ${ }^{5}$ But is this really the case? This brings us to our first working hypothesis and that is to find out which approach is truly accepted in attempt provision in the Rome Statute.

In the theory of criminal law, there are three possible approaches towards interpretation of ratio legis of criminal attempt: subjective, objective and subjective-objective. These approaches have been discussed in details in comparative literature. In this paper, we will give only a brief overview of these approaches.

The subjective approach emphasises the mental element of the attempt. To justify punishment for the attempt, subjective approach points out that, the perpetrator who attempted to commit the crime has the same mens rea (in Continental legal terminology that would be intent or dolus) as the one who actually managed to complete the crime. Whoever shot and missed obviously had the same intent to kill the victim as the one who shot and killed. Consequently, the attempt should be punished same as completed crime. Besides, the so-called impossible attempts (Ger. der untaugliche Versuch), such as shooting with an empty gun or at an already dead body without knowledge thereof, should be punished same as every other attempt.

\footnotetext{
${ }^{5}$ For details of the ILC's opinion and comment see Albin Eser, Individual Criminal Responsibility (Art. 25 Rome Statute), Transnationales Strafrecht/Transnational Criminal Law, Gesammelte Beiträge/Collected Publications 463-464 (Albin Eser ed., Berlin: BWV-Berliner WissenschaftsVerlag 2011).
} 
The opposite approach is objective approach. It sees the essence of the attempt in objective element or actus reus. The attempt is punishable because the object (the victim) was endangered. However, one must admit that, such endangerment is significantly less than if the crime was completed. Consequently, in case of inchoate crimes, the court should always mitigate the sentence and the impossible attempt should not be punishable at all.

Finally, the third approach combines the two opposites and sees the purpose of the attempt in criminal will or mens rea that was carried out by endangerment of the object. Accordingly, this approach also favours mitigation of sentence (objective approach) but only as an option for the judge, not as a mandatory obligation (subjective approach). Besides, this approach recognizes the effect of impossible attempt (objective approach) but it also leaves it to the court to decide whether it will draw any privileges to the perpetrator of the impossible attempt (subjective approach). This approach is considered to be the modern one in criminal law. ${ }^{6}$ Further in this paper, we will adopt this approach and our suggestions de lege ferenda will be modelled on it.

Despite an official explanation given by the ILC mentioned above, we can object that, the text of Art. 25/3/f is founded on subjective-objective theory. That is easy to notice if one considers that, the Rome Statute does not predict the possibility of mitigation of a sentence, at least not expressis verbis. Moreover, it does not even regulate the institute of impossible attempt. These two features are two main requirements of the objective part of mixed subjective-objective approach. Consequently, we can give an answer to our first working hypothesis: Art. 25/3/f favours only the subjective approach, which is today considered to be obsolete and inadequate. $^{7}$

It seems that, the subjective approach is also favoured in the jurisprudence of the ICC. In its Decision on the Confirmation of the Charges in Katanga case, Pre-Trial chamber I emphasizes the subjective element of the attempt by pointing to the following:

"The majority of the Chamber endorses the doctrine that, the attempt to commit a crime is a crime in which the objective elements are incomplete while the subjective elements are complete. Therefore, the dolus that embodies the attempt is the same as the one that embodies the consummated act."

\footnotetext{
${ }^{6}$ For more about all three approaches see f. e. Claus Roxin, Strafrecht. Allgemeiner Teil, Band II, Besondere Erscheinungsformen der Straftat, 9-58 (München: Verlag C. H. Beck 2003), § 29.

${ }^{7}$ See supra note 3, 32-45.

${ }^{8}$ Katanga, et al. (ICC-01/04-01/07), Decision on the Confirmation of the Charges, September 30, 2008, paras. 458-460.
} 
After analyses of ratio legis of the attempt in the Rome Statute, we are able to give our own remarks on how to improve this provision de lege ferenda. In our opinion, instead of favouring the subjective approach, the Rome Statute should consequently follow the idea given by the ILC and accept the mixed approach. This would certainly harmonize Art. 25/3/f in accordance with modern criminal codes in most countries of Continental Europe. This could be accomplished by introducing the expressis verbis possibility of mitigation of the sentence for the attempt as well as introducing the provision of impossible attempt. The possibility of mitigation of punishment is necessary if one wants to distinguish attempted from completed act. A contrario if there is no privilege for the attempt, it is not possible to estimate the gravity of these two stages of criminal offence. That is the main purpose of attempt provision in the general part.

Impossible attempt is a very important institute in criminal law recognized not only in Continental Europe, but also in Anglo-American law. Fletcher explains this legal figure on the example of the perpetrator who thinks that, a stump is the man he wants to kill and shoots at it or a perpetrator who puts sugar in his victim's coffee and he mistakenly believes that, the sugar is poison. ${ }^{9}$ In international crimes, impossible attempt would be possible in a case where for example a soldier would shoot a civilian who was already dead at the time of shooting.

Impossible attempt is important if one wants to implement a mixed, subjective-objective legislative model. As we have already explained, in cases of impossible attempt there is sufficient mens rea, but insufficient actus reus. If these two elements have the same gravity, the legislator has no other option but to make the principle distinction between possible and impossible attempt. There are two possible solutions: To regulate this situation as a ground for excluding criminal liability or only as a ground for mitigation or acquittal from punishment. Other solution is accepted in every modern European criminal code today. Of course, these legal effects are possible only if the perpetrator has acted by a huge lack of understanding that he cannot complete the act.

\section{REMARKS ON THE ABANDONMENT OF CRIMINAL ATTEMPT: BROADENING THE SCOPE OF ABANDONMENT?}

Voluntary abandonment from criminal attempt represents one of the core-institutes of general part of substantive criminal law. Article 25/3/f

\footnotetext{
${ }^{9}$ George P. Fletcher, Rethinking Criminal Law 146 (New York-Oxford: Oxford University Press 2000).
} 
regulates this institute for the first time in the history of international criminal law. ${ }^{10}$ It regulates a situation in which the perpetrator completely voluntarily and without any force gives up his conduct in the attempt phase, although he is well aware that, there are no objective factors which could stop him from completing the act. His motives for such acting can be different: Remorse or pity, lack of interest, fear of consequences if he gets discovered later etc. The motive is not important and what is important is that, the perpetrator acts voluntarily and that his actions are not motivated by any obstacles which could prevent him from completing the act. Probably the best theory that enables the court to estimate when the abandonment is voluntary is the one developed by Roxin, who suggests the adoption of the «average perpetrator's logic» criterion. In that sense, the abandonment is voluntary only if it is not logical from the perspective of an «average» perpetrator. For example, it is not logical that, the rapist abandons the attempted rape only due to remorse towards the victim if he knows that, he cannot be discovered in any way because there are no witnesses and the victim has not recognised him.

Situations of voluntary abandonment from criminal attempt are quite rare because it is not often that, a perpetrator who acts with intent suddenly and without any objective reason changes his mind and even takes an effort to prevent the consequences of attempted criminal offence. Considering that, it is no wonder that, there has not been a single case of voluntary abandonment before the ICC. However, this institute is regulated in almost every Continental European criminal code and even some authors from England and Wales claim that, the defence of voluntary abandonment should be considered as part of the common law. ${ }^{12}$ In English literature, there are only a few decisions mentioning which courts, although they did not recognize abandonment as a defence, have mitigated the punishment in such cases. ${ }^{13}$

\footnotetext{
${ }^{10}$ Abandonment provision was implemented as a result of proposal of Japanese delegation. See more in William A. Schabas, The InTERNATIONAL Criminal CourT 439-440 (Oxford: Oxford University Press 2010).

${ }^{11}$ Claus Roxin, Strafrecht. Allgemeiner Teil, Band II, Besondere Erscheinungsformen der Straftat, 383-386 (München: Verlag C. H. Beck 2003), § 30.

${ }^{12}$ See R. A. Duff, Criminal Attempts 66-75 (Oxford: Clarendon Press 1996); see also A. P. Simester, J. R. Spencer, G. R. Sullivan, \& C. J. Virgo, Siemester and Sullivan's Criminal Law, Theory and Doctrine, 342-343 (4th ed., Oxford and Portland: Hart Publishing 2010). For opposite see f. e. J. C. SMith, \& BRIAN Hogan, CRiminal LAW 299-300 (6th ed., London-Edinburgh: Butterworths 1988); and William Wilson, Criminal LaW: Doctrine AND Theory 543 (2th ed., Harlow: Pearson Education Limited, 2003).

${ }^{13}$ See Mathias Brockhaus, Die Strafrechtliche Dogmatik von Vorbereitung, Versuch und Rücktritt im europäischen Vergleich, Unter Einbeziehung der Aktuellen Entwicklungen zur 'Europäisierung' des Strafrechts, 386-387 (Hamburg: Verlag dr. Kovač 2006).
} 
A comparative overview shows that, different systems give voluntary abandonment more or less gravity. There are systems such as for example the German, Austrian, Swiss, French, Spanish or Russian systems, which regulate voluntary abandonment from criminal attempt as grounds for excluding criminal liability. On the other hand, some legislators have decided to leave criminal liability untouched and to solve the problem in the sphere of sentencing. Such systems usually predict a possibility of mitigating the punishment or, in some cases, releasing from punishment, but criminal liability remains. The examples of such systems in Europe exist in the Croatian, Serbian, Slovenian, Macedonian and Hungarian criminal codes. However, these systems are in minority and they are often characterised by the lack of systematic theoretical debate about voluntary abandonment in their criminal law literature. ${ }^{14}$

The leading theory about ratio legis of abandonment privilege in modern literature is the so-called «theory of the purpose of punishing» (Germ. Strafzwecktheorie), developed by Claus Roxin. This theory has the greatest number of followers in modern literature. The basic idea of this theory is that, in case of the perpetrator who has voluntarily abandoned his efforts to finish the attempt, there is no point to insist on conviction and punishment. Namely, criminal law conviction and punishment are based on the need for general and special prevention. That is the main justification of punishment and also of the criminal law system. If that justification fails, there is no ground for further criminal liability and any conviction or punishment will not be legitimate. Although this concept gives a relatively good explanation of the privilege, it is important to notice that, it is based on Roxin's specific concept of criminal conduct, according to which one of the constitutive elements of criminal conduct is the so-called «necessity of preventive acting». ${ }^{15}$

The creators of the Rome Statute obviously considered voluntary abandonment as an important legal institute since they regulated it as one of the grounds for exclusion of criminal liability. As already mentioned above, there are systems that regulate abandonment only in sentencing area, as a ground for mitigation or release from punishment. Legal regulation of

\footnotetext{
${ }^{14}$ On comparative overview of voluntary abandonment in European legal systems see ibid. Details about the Serbian system can be found in Igor Vuletić, Legal Regulation of Voluntary Abandonment from Criminal Attempt-German Solutions and Serbian Potentials, InTRODUCTION TO GERMAN LAW 349-372 (Mirko Vasiljević \& Vladimir Čolović eds., Belgrade: Institute of Comparative Law 2011).

${ }^{15}$ See Strafrecht. Allgemeiner Teil, Band II, Besondere Erscheinungsformen der Straftat, 7 (München: Verlag C. H. Beck 2003), §30. This theory is accepted, not only by the majority of German authors, but also by authors outside Germany. See f. e. KeiichiYamanaka, Betrachtungen über den Strafbefreiungsgrund des Rücktritts vom Versuch in Bernd Schünemann/Claus Roxin, Festschrift für Claus Roxin zum 70. Geburtstag am 15. Mai 2001787 (Berlin-New York: Walter de Gruyter 2001).
} 
voluntary abandonment can be based on two main types of legislative approaches.

The first approach-we will name it subjective-emphasises the subjective component: voluntariness. The main characteristic of such a system is legal possibility of the so-called non-causal abandonment (see below). The second approach - we will name it combined or subjectiveobjective - gives equal value and gravity to both, subjective (voluntariness) and objective (abandoning the effort to complete the crime and/or preventing the consequence) components. These systems do not recognize the possibility of non-causal abandonment. Now, we can draw up the second working hypothesis in this paper: To define which type of legislative approach is implemented in the Rome Statute.

The creators of the Rome Statute have chosen quite an unusual model of "double" regulation of voluntary abandonment of criminal attempt. The first part of this regulation is in the second part of the first sentence of Art. $25 / 3 / \mathrm{f}$. ${ }^{16}$ This is the so-called implicit or negative regulation of voluntary abandonment. Implicit definition has its role model in Art. 121-5 of the French Code Pénal. The second part of the regulation is the so-called explicit or positive model, which is contained in the second sentence of Art. 25/3/f. ${ }^{17}$ This provision was introduced at the insistence of Japan, Argentina and Germany, who claimed that, voluntary abandonment is one of the traditional institutes of criminal law that exists in most of developed criminal law systems in the world. Explicit definition is primarily based on the modified Siracusa Draft of 1996 and $\S 5.01 / 4$ of Model Penal Code (hereinafter: MPC). ${ }^{18}$

This kind of double regulation of voluntary abandonment of criminal attempt is very atypical. Some authors claim that, it is an editorial error. ${ }^{19}$ The comparative overview for European countries shows dominance of explicit or positive regulation, ${ }^{20}$ while negative regulation is accepted only

\footnotetext{
${ }^{16}$ Art. 25/3/f:, first sentence: "Attempts to commit such a crime by taking action that commences its execution by means of a substantial step, but the crime does not occur because of circumstances independent of the person's intentions."

${ }^{17}$ Art. 25/3/f, second sentence: “... a person who abandons the effort to commit the crime or otherwise prevents the completion of the crime shall not be liable for punishment under this Statute for the attempt to commit that crime if that person completely and voluntarily gave up the criminal purpose."

${ }^{18}$ Katrin Schubert, Der Versuch —Überlegungen zur Rechtsvergleichung und Harmonisierung, 243 (Berlin: Duncker \& Humblot 2005).

${ }^{19}$ Kai Ambos, Der Allgemeine Teil des Völkerstrafrechts, 755 (Berlin: Duncker \& Humblot 2002).

${ }^{20}$ Positive regulation is, for example, accepted in criminal codes of Germany, Switzerland, Spain, Austria, Russia, Croatia, Serbia and Denmark. See Matthias Brockhaus, Die Strafrechtliche Dogmatik von Vorbereitung, Versuch und Rücktritt im Europäischen Vergleich, Unter Einbeziehung der Aktuellen Entwicklungen zur «Europäisierung» des Strefrechts, 139-275, 399-415 (Hamburg: Verlag Dr. Kovač 2006).
} 
in the French, Belgian and Luxemburg law and it is considered to be outdated. ${ }^{21}$ Negative regulation assumes that, criminal attempt is constituted of one positive element-beginning of an attempt-and one negative element-missing of voluntary abandonment.

We think that, negative regulation in the second part of the first sentence should be deleted. It is unnecessary and it only causes confusion, especially in terms of legal effect of voluntary abandonment on accomplices. Namely, the Rome Statute regulates voluntary abandonment as one of the grounds for excluding criminal liability («shall not be liable for punishment»). If one interprets voluntary abandonment as a negative element of an attempt, this means that, abandonment excludes the mere existence of attempted criminal offence. If that is the case, then the consequence is that, due to the accessoriness principle, not only the perpetrator who abandoned, but also the accomplices who did not abandon or did not even want to abandon, must also be excluded from criminal liability. ${ }^{22}$ This is a paradox and untenable solution. If $\mathrm{A}$ shoots at $\mathrm{B}$ and then changes his mind and calls an ambulance and saves his life, there is no reason to privilege $\mathrm{C}$ who was A's aider or abettor (because he gave him a gun) and did not have anything to do with A's abandonment. To avoid such interpretations, we suggest deleting the second part of the first sentence of Art. 25/3/f and keeping only the positive formulation from the second sentence.

Furthermore, positive regulation from the Statute is only partially successful, because it neither regulates non-causal abandonment nor says anything about the abandonment of the accomplices. Non-causal abandonment is a situation where a person tries to abandon the effort to commit the crime but somebody else (or something else) prevents the consequence. For example, A shoots at B, leaves the place of crime but then changes his mind and returns to help B. When he arrives, he sees that, someone else has already called an ambulance and that $\mathrm{B}$ has been medically treated. In this case, the damage is prevented, only not by the perpetrator's contribution but by someone else's contribution. These cases are recognized as cases of voluntary abandonment in several European legal systems. ${ }^{23}$ Moreover, cases of non-causal abandonment are also mentioned in Anglo-American literature. In his book, Criminal Attempts Duff discusses

\footnotetext{
${ }^{21}$ See supra note 8, 193-196, 198-199.

${ }^{22}$ Same Vlado Kambovski, Dobrovoljni Odustanak od Izvršenja Krivičnog Djela, 45 (Skoplje: Faculty of Law 1974).

${ }^{23}$ See for example $\S 24 / 1$ of the German Criminal Code, $\S 16 / 2$ of the Austrian Criminal Code, Art. $23 / 3$ of the Swiss Criminal Code and Art. 35/2 of the Croatian Criminal Code.
} 
an example of "Mr. Grant" who puts the bomb into an airplane and sets the timer so that the bomb explodes in the air. Then he changes his mind and tries to disable the bomb but someone else had already done it or the bomb had exploded on the ground while the airplane was still empty. Duff points out that, these situations have to be taken into consideration by the court. ${ }^{24}$

If we take the above mentioned elements of voluntary abandonment into consideration, we can answer our working hypothesis: Art. 25/3/f accepts a mixed approach. This is easy to conclude if one bears in mind that, the Statute does not regulate the possibility of non-causal abandonment. Moreover, we can notice that, the Statute allows abandonment in a very narrow scope because it does not regulate the possibility of abandonment for accomplices.

We approve of the legislative approach, which favours non-causal abandonment because we believe that, the emphasis should be on a subjective component-voluntariness of the abandonment. Voluntariness demonstrates rejection of original criminal intent and justifies the privilege for the perpetrator. Only the perpetrator who voluntarily rejected his original intent (dolus) to commit the crime can be excluded from criminal liability. From the objective point of view, it is sufficient that consequence was prevented. Non-causal abandonment should, therefore, be a part of future abandonment provision in the Rome Statute.

The abandonment of accomplices raises specific issues, which is why it should also be regulated in the Statute. All the above mentioned systems that accept the positive approach at the same time predict a provision regulating this question. The most common legislative solution is to predict that, the accomplice who wants to abandon, should prevent others from finishing the attempt. Such provisions can be found for example in the German, Austrian, Swiss, Croatian and Serbian criminal codes. The German law goes even further when it recognizes the possibility of non-causal abandonment of accomplices. That is the case in which, for example, A wants to abandon armed robbery, so he leaves the crime scene and calls the police but then finds out that somebody has already called the police and that the police has arrived and prevented the rest of the robbers from escaping (see $\S 24 / 2$ of the German Criminal Code). In our opinion, the best solution is to add another sentence in Art. 25/3/f regulating abandonment of accomplices. We suggest to use the German provision as a role-model and to allow the possibility of non-causal abandonment of accomplices. This is consistent to our opinion that voluntary abandonment is characterised by its

\footnotetext{
${ }^{24}$ R. A. DufF, CRiminAl AtTEMPTS 66-75 (Oxford: Clarendon Press 1996).
} 
specific subjective nature-rejection of original criminal intent.

\section{DRAFT OF THE FUTURE ART. 25/3/F}

In order to give our own original contribution to this debate, we will offer our own draft of the future structure of Art. 25/3/f of the Rome Statute. We will then explain on each of the suggested changes. According to our idea, the future provision of Art. 25/3/f of the Rome Statute should be as follows:

(1) Attempts to commit such a crime by taking action that commences its execution by means of a substantial step, but the crime does not occur. An attempt may be punished more leniently than the completed act. If the perpetrator, due to huge lack of understanding, fails to recognize that, the attempt could not possibly lead to completion due to the nature of the object on which, or the means with which it was to be committed, the court may withhold punishment or in its own discretion mitigate the punishment;

(2) However, a person who voluntarily abandons the effort to commit the crime or otherwise prevents the completion of the crime or puts an effort to prevent them and the crime does not occur for other reasons, shall not be liable for punishment under this Statute for the attempt to commit that crime if that person completely and voluntarily gave up the criminal purpose. An accomplice who voluntarily prevents others from completing the crime or puts an effort to prevent them, and the crime does not occur for other reasons, shall not be made liable.

The suggested provision has two subparagraphs. We think they are necessary if one wants to clearly distinguish between these two institutes of criminal law. The attempt is defined in subparagraph (I) in the same way as before only without the abandonment as its negative element. The second sentence predicts the possibility of mitigation of punishment as a potential privilege to the perpetrator. The third sentence introduces the institute of impossible attempt into the Rome Statute due to a huge lack of understanding and it is identical to $\S 23 / 3$ of the German Criminal Code (Germ. Strafgesetzbuch, hereinafter: StGB). Such structure of this article is consistent with subjective - objective approach as proclaimed by the ILC.

Abandonment is regulated in subparagraph (II) and based mostly on $\S$ 24 of StGB. The same as in StGB, the new provision predicts the possibility of non-causal voluntary abandonment for a single perpetrator as well as for the accomplices. It is emphasized that, the abandonment must be taken voluntarily. These changes express the acceptance of subjective approach towards the regulation of this core institute of criminal law. This solution 
follows modern trends in criminal law.

\section{CONCLUSION}

In this paper, we have given a brief overview of Art. 25/3/f of the Rome Statute. This article regulates the institutes of attempt and voluntary abandonment of an attempt. The mere existence of such a provision represents a huge progress in international criminal law because earlier statutes of ad hoc tribunals did not contain any similar provisions.

However, we think that, there is a lot of space for further progress of international criminal law in this area. We strongly believe that, the creators of the Statute did not use all potentials of these two institutes.

As for regulation of criminal attempt, we think that, the ideas of modern subjective-objective approach have not been completely adopted in the Statute. It is still necessary to introduce possible mitigation of punishment and to regulate impossible attempt. We think that, a good legislative model for these changes can be found in $\S 23$ of the German StGB.

As for voluntary abandonment from criminal attempt, we think that, double (positive and negative) regulation is confusing and unnecessary. Negative regulation is outdated and it has been abandoned in most of developed European criminal law systems. Therefore we believe that, the Rome Statute should keep only positive regulation. Moreover, it should expand the scope of this institute by introducing the possibility of noncausal abandonment and by regulating the abandonment of the accomplices. One must not forget that, voluntary abandonment represents positive and socially acceptable behaviour because it demonstrates rejection of criminal attempt. That is why the emphasis should be on the subjective componentvoluntariness of the abandonment. In this sense, we think that, the good legislative model for these changes can be found in $\S 24$ of the German StGB.

We advocate German legal solutions mostly because legal regulation of the attempt and voluntary abandonment has been a great challenge for German authors for the past fourty years. In German literature, there are many monographs, dissertations and numerous articles on almost every possible problem aspect of these two institutes. Some of the most famous names of the German criminal law theory have written a lot about this issue. The result thereof is that, German literature and jurisprudence can be used also for the interpretation of the Rome Statute in this field of criminal law. 